\section{Vocal displays under water by the gray seal, the harbor seal, and the stellar sea lion}

RONALD J. SCHUSTERMAN, RICHARD F. BALLIET, and STANLEY ST. JOHN, Stanford Research Institute, Menlo Park, Calif. 94025

Study was made of the vocal repertoires of three species of seals and sea lions which, until now, have been reported as not being very vocal under water. Sonograms of underwater vocalizations are presented for the gray seal and the harbor seal for the first time. In all cases, underwater vocalization occurred within a social context, and it was noted that many of the vocalizations emitted under water may also be emitted in air.

Within the past 2 years, several reviews have appeared dealing with various aspects of underwater vocalizations and sounds produced by a variety of pinniped species of the families Phocidae and Otariidae (Evans, 1967; Poulter, 1968; Schusterman, 1967; Schusterman, 1968; Norris, 1969). Although underwater sounds of seals and sea lions have been recorded both in the wild and in captivity, there has been only a limited sampling of the vocal repertoire of any given species, and as yet there is still relatively little understanding of the biological significance of pinniped

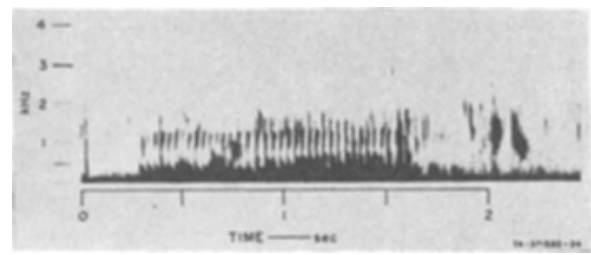

Fig. 1. Sound spectrogram of an underwater belch vocalization from a 3-year-old male Steller sea lion. Analyzing filter bandwidth, $300 \mathrm{~Hz}$.

Fig. 2. Sound spectrograms of underwater growl-type vocalizations from three different harbor seals. Analyzing filter bandwidth, $300 \mathrm{~Hz}$. case of two of these species we are unaware of any published spectrograms) or have been reported to emit only underwater clicks (Evans, 1967; Poulter, 1968; Schusterman, 1968; Schevill, Watkins, \& Ray, 1963).

vocalizations under water. However, on the basis of our own recordings and observations and those of others, it appears that many underwater calls are variable both within and between species, especially in terms of frequency structure and temporal patterning. Another conclusion that we are beginning to draw from our own research and that of others is that the majority of these vocal emissions are primarily a function of social behavior. For example, a recent study has shown that some underwater vocalizations (barking) by male California sea lions (Zalophus californianus) are clearly related to their social organization (Schusterman, 1968; Schusterman \& Balliet, 1969; Schusterman \& Dawson, 1968). Moreover, many of the vocalizations that can be emitted in air can be made under water as well, and, if the neck and body of the animal remain submerged, the call becomes an amphibious signal, i.e., it is projected under water and in air at the same time.

This paper reports on the underwater vocal displays of three species of pinnipeds that hitherto have been reported as either not being very vocal under water (in the

\section{STELLER SEA LION}

(Eumetopias jubata)

This species hauls out and sometimes breeds on small islands in the north Pacific with a range extending to offshore islands of central and southern California and northern Japan (Scheffer, 1958). Despite the fact that Steller sea lions are quite vocal in air, usually emitting belching and hissing sounds that function primarily as a threat and are frequently related to the territorial behavior of the large bulls during the breeding season (Gentry, 1968; Orr \& Poulter, 1967), only very recently have we been able to record any underwater vocalizations from this species in captivity. In all previous attempts to record their underwater vocalizations, we placed a single Steller sea lion in a free-swimming situation. Since we have noted that many of the vocalizations by Zalophus were produced during social encounters, we decided to record Eumetopias in the presence of other animals under water, and were finally successful in obtaining underwater vocalizations from this species. A sonogram depicting a series of underwater clicks emitted by a 3-year-old

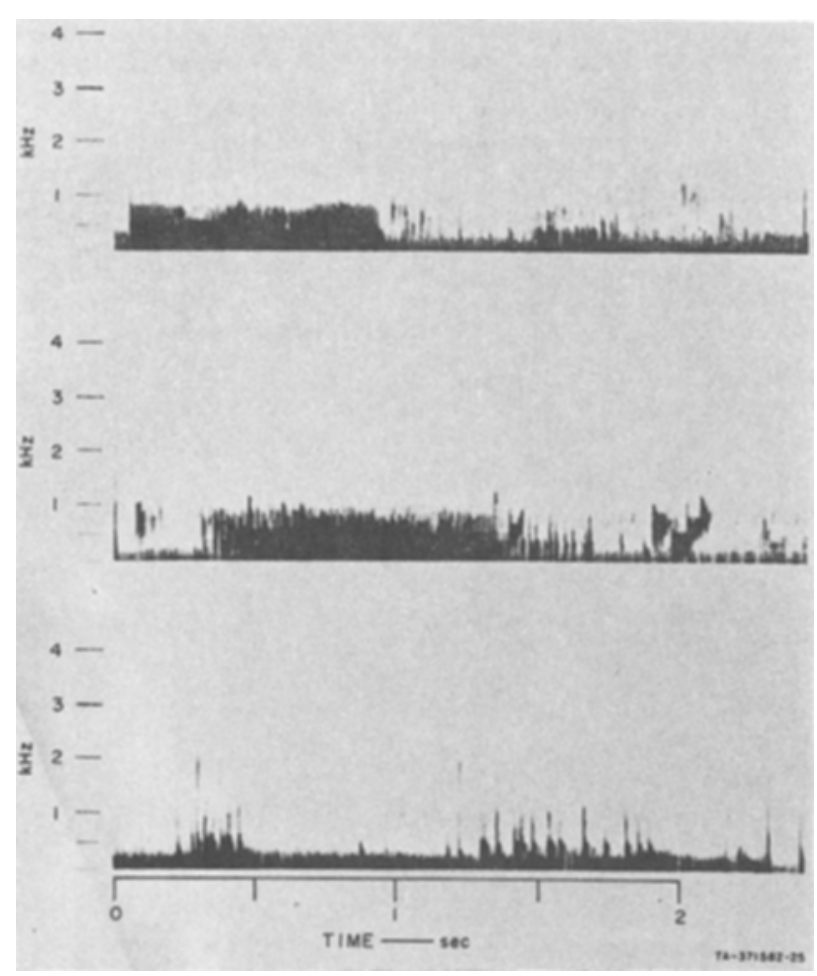

Psychon. Sci., 1970, Vol. 18 (5) 
male Steller sea lion is shown in Fig. 1. The recording was made while the animal was interacting with several male and female Zalophus in a concrete pool, $3.05 \mathrm{~m}$ in diam and $0.9 \mathrm{~m}$ deep. The sonogram shows that this animal produces a series of rather discrete, low-frequency pulses that are very characteristic of the aerial vocalization that the male of this species frequently emits. This sound has been called "belching" by several investigators. These pulses occur at the rate of approximately 20 to $30 / \mathrm{sec}$, which seems to be a relatively normal average rate of pulses emitted by Eumetopias both in air and under water. As in the case of barking and clicking by Zalophus, this belch vocalization by Eumetopias may also become an amphibious signal if the neck of the animal is submerged.

\section{HARBOR SEAL}

(Phoca vitulina)

As with Eumetopias, until very recently we had not been able to record underwater vocalizations from Phoca, even though we had attempted to do so on several occasions while individual seals were in various kinds of free-swimming and discrimination situations. Recently, we were successful in recording the vocalizations of these seals while they were swimming with members of their own species as well as with Zalophus and Eumetopias in a 3.4-m concrete pool, $0.9 \mathrm{~m}$ deep. Sonograms of these calls, shown in Fig. 2, indicate that the underwater vocalizations of these animals are of a pulsed nature, with low frequencies predominating. The rate at which these pulses are emitted is quite variable. In one case, the pulse repetition rate was so rapid and loud that the call sounded like a roar. In other instances, the pulse repetition rates have been quite slow. All of these sounds emitted under water have also been emitted in air and have been frequently associated with foreflipper waving and other postures and movements indicative of a threat display.

GRAY SEAL

(Halichoerus grypus)

These seals have been found to haul out and sometimes establish rookeries on rocky coasts and sandy coves as well as isolated offshore islands around the British Isles and in North America around

Fig. 3. Sound spectrograms of underwater clicks (analyzing filter bandwidth, $300 \mathrm{~Hz}$ ), humming sounds (analyzing filter bandwidth, $45 \mathrm{~Hz}$ ), and a mooing-type sound (analyzing filter bandwidth, $45 \mathrm{~Hz}$ ) by two gray seals. On the third graph, we believe the short pulses at and above $2 \mathrm{kHz}$ were produced by water turbulence.
Newfoundland, Nova Soctia, and the Gulf of St. Lawrence. Both in the western Atlantic colonies and in the British colonies, gray seal bulls have been reported to establish territories (Hewer \& Backhouse, 1960), sometimes using natural markings in the terrain as boundary demarcations (Cameron, 1967). However, little has been reported concerning vocal displays either from territorial bulls, females, or pups. It has been suggested that Halichoerus may not be very vocal under water (Poulter, 1968). However, in 1963, Schevill, Watkins, \& Ray (1963) reported obtaining a series of clicks from gray seals in captivity (obtained in the St. Lawrence region of Canada). They reported that the clicks sometimes were apparently random and at other times were repeated in series at about the rate of $60 / \mathrm{sec}$, with frequencies near $6-12 \mathrm{kHz}$ predominating. We recently recorded a male and female when they were about 6 or 7 months of age in the same pool in which Phoca vitulina was recorded. These animals were captured as pups (about 6 weeks old) on
Prince Edward Island, Newfoundland, and have been maintained in our laboratory ever since. Based on our analysis, young gray seals apparently produce three or four different types of sounds while submerged. They emitted a rapid series of clicks, which sometimes sounds like a frequency-modulated buzz-some of the rates being between 70 and 80 clicks $/ \mathrm{sec}$, with a frequency range between $0.5 \mathrm{kHz}$ and possibly $12 \mathrm{kHz}$. Continuous high-pitched humming or moaning sounds, which sound something like a dog crying in its sleep, sometimes with a degree of frequency modulation giving it a slight yodeling quality, and mooing-type sounds have also been recorded under water (see Fig. 3). During a 1.h observation period, we recorded 12 distinct instances of harmonically rich humming calls as compared to six separate and distinct series of clicks. The median duration of the former calls was $2.1 \mathrm{sec}$, with a range of 0.9 to 2.6 sec. In observing the gray seal pair during these vocal emissions, it was noted that the calls were produced only

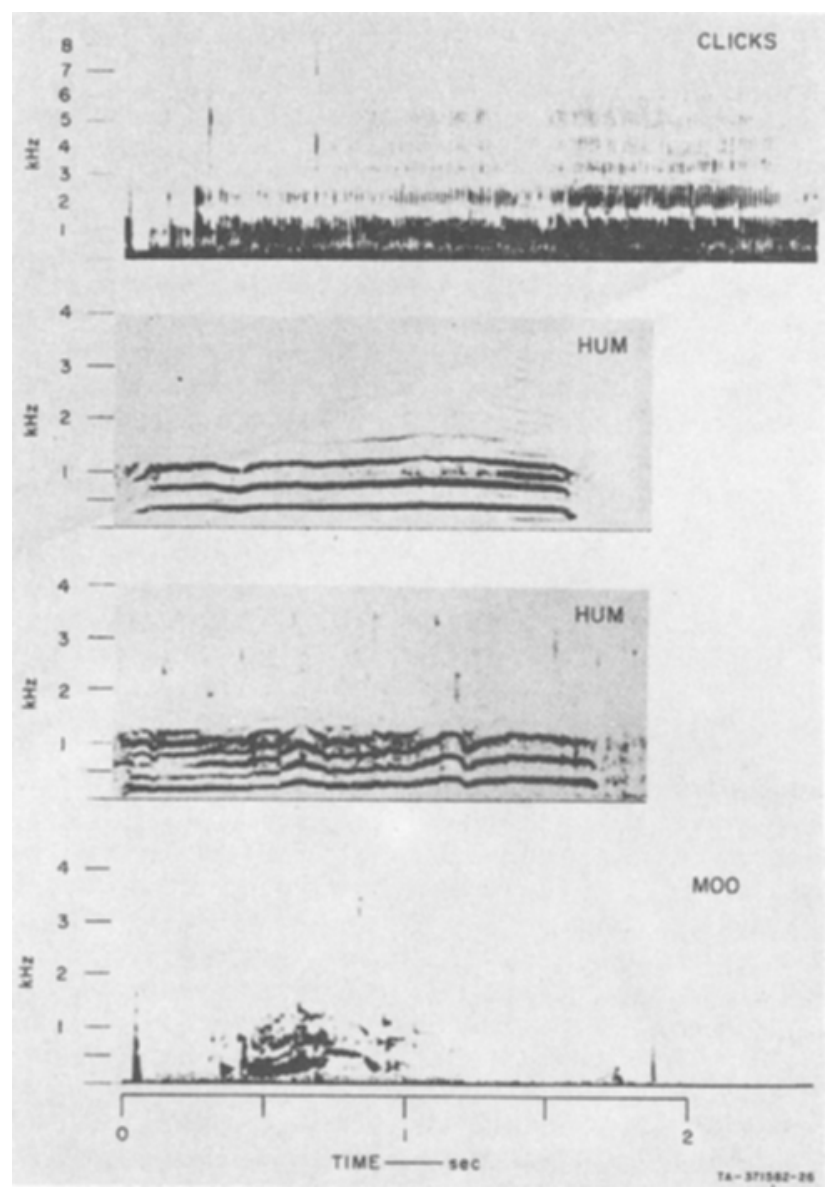




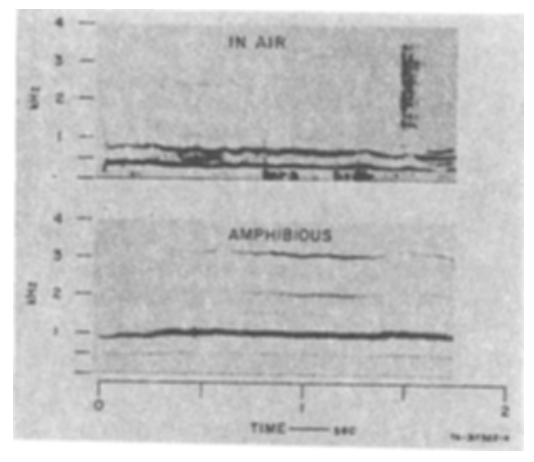

Fig. 4. Sound spectrograms of aerial and amphibious calls by gray seals (analyzing filter bandwidth, $45 \mathrm{~Hz}$ ). The amphibious call was recorded under water. Ignore background noise at the end of the in-air recording.

when the animals were interacting socially. Even in the case of the clicks, the animals were either chasing one another, in physical contact with one another, or orienting toward one another. It should be added that the water the animals were swimming in was extremely clear.

Thus, in the case of the gray seals, as with several other species we have studied, it seems that despite the fact that clicks suggest the possibility of echolocation, these sounds probably play a key role in the social communication systems of these animals. The humming sounds, as well as some of the short pulsed sounds (clicks), are produced in air as well as under water, and are sometimes projected "amphibiously," i.e., both in air and under water simultaneously (see Fig. 4). Thus, like Zalphus, Eumetopias, and Phoca. Halichoerus emit many of the same sounds under water that are emitted in air.

Underwater vocalizations were monitored and recorded by a Channel Industries 275 hydrophone and a Uher $4000-S$ tape recorder at $20 \mathrm{~cm} / \mathrm{sec}$. The tapes were rerecorded on a Uher $4000-\mathrm{S}$ and were analyzed by a Kay 661 audio spectrum analyzer in conjunction with an Ampex tape recorder.

\section{REFERENCES}

CAMERON, A. W. Breeding behavior in a colony of Western Atlantic gray seals. Canadian Journal of Zoology, 1967, 45, 161-173.

EVANS, W. E. Vocalization among marine mammals In W. N. Tavolga (Ed.), Marine bio-acoustics. Vol. 2. New York: Pergamon, 1967. Pp. 159-186.
GENTRY, R. L. Territoriality and reproductive behavior in male Steller sea lions. American Zoologist, 1968, 8, 739 (Abstract).

HEWER, H. R., \& BACKHOUSE, K. M. A preliminary account of a colony of gray seals (Halichoenus grypus Fab.) in the southern Inner Hebrides. Proceedings of the Zoological Society of London, 1960, 134, 157-194.

VORRIS, $K$. The echolocation of marine mammals. In H. T. Anderson (Ed.), The biology of marine mammals. New York: Academic Press, 1969. Pp. 391-423.

ORR, R. T., \& POULTER, T. C. Some observations on reproduction, growth, and social behavior in the Steller sea hon. Proceedings of the Califomia Academy of Science, 1967, 35, 193-225.

POULTER, T. C. Marine mammals. In T. Seboek (Ed.), Animal communication. Bloomington, Ind.: Indiana University Press, 1968 Pp. 405-465.

SCHEFFER, V. B. Seals, sea lions and walruses. $A$ review of the Pinnipedia. Pato Alto, Calif: Stanford University Press, 1958.

SCHEVILL, W. E., WATKINS, W. A., \& RAY, C.
Underwater sounds of pinnipeds. Science, 1963. 141. 50-53.

SCHUSTERMAN, R. J. Perception and determinants of underwater vocalization in the California sea lion. In R. G. Busnel (Ed.), Les systemes sonars animax. Jouy-en-Josas, France: Laboratoire d'Acoustique Animale, 1967. Pp. 535-617.

SCHUSTERMAN, R. J. Experimental laboratory studies of pinniped behavior. In R. J. Harrison, R. C. Hubbard, R. S. Peterson, C. E. Rice, and R. J. Schusterman (Eds.), The behovior and physiology of pinnipeds. New York: Appleton-Century-Crofts, 1968. Pp. 87-171. SCHUSTERMAN, R. J., B BALIET, R. F. Underwater barking by male sea hons (Zalophus californianus). Nature, 1969, 222, 1179-1181.

SCHUSTERMAN, R. J., \& DAWSON, R. G. Barking, dominance and territoriality in male sea lions. Science, 1968, 160, 434-436.

NOTE

1. This research was supported by NSF Grant GB-7039.

\section{Pentobarbital-induced state-dependent learning of one-way avoidance in mice}

\section{LAWRENCE BROWNE, ${ }^{2}$ FRED JUDGE, and PHYLLIS KASPER-PANDI, ${ }^{3}$ Sir George Williams University, Montreal, P.Q., Canada}

Four groups of eight albino mice were trained to avoid shock in a one-way avoidance situation. Two groups received pentobarbital sodium during training and two groups received saline. One day after having reached the learning criterion, the mice received one test trial. Prior to the test trial, two groups received the same treatment they had received during training, and two received the other treatment. All 16 mice receiving the same treatment avoided on the test trial, whereas only 4 of the 16 mice receiving the change in treatment successfully avoided. Pentobarbital did not affect the rate of original learning of the one-way avoidance response.

In 1964, Donald Overton found that rats could be trained to make one directional response in a maze to escape shock after having been injected with pentobarbital and the opposite response after having been injected with a placebo. This absence of transfer of training between drug and nondrug states is referred to as "dissociated" or "state-dependent" learning. It has been obtained with a variety of such drugs as chlordiazepoxide (Sachs, Weingarten, \& Klein, 1966), amobarbital (Barry, Etheredge, \& Miller, 1965), phenobarbital (Bindra, Nyman, \& Wise, 1965), and depressant and atropine-like drugs (Overton, 1966).

The purpose of the present study was to produce dissociation of one-way avoidance learning in mice through the use of pentobarbital sodium. Since much of the current literature on drug dissociation involves rats, and since mice are commonly used as Ss in screening drugs, it was considered of interest to demonstrate state-dependent learning in mice.

$$
\text { SUBJECTS }
$$

The Ss were 32 mature male albino mice with an average weight of $26 \mathrm{~g}$. They were housed in groups of eight in a room with an 8 a.m.-10 p.m. light-dark cycle.

\section{APPARATUS}

The one-way avoidance box was made of unpainted plywood, measured $12 \times 6 \times 10$ in., and had a Plexiglas lid. A black center wall with a door divided the box into two equal chambers. The grid floor was wired for shock in the chamber 